\title{
СЕМИОТИКА НАРРАТИВА В ОРИГИНАЛЕ И ПЕРЕВОДЕ РОМАНА К. ВОННЕГУТА «КОЛЫБЕЛЬ ДЛЯ КОШКИ»
}

Статья рассматривает нарративные элементы художественного текста сквозь призму семиотики. Утверждается, что структура художественного текста и использование определенных нарративных техник создают уникальное внутритекстовое семиотическое пространство. Приводятся примеры лексико-семиотических рядов, демонстрируюших смену нарративных техник в художественном тексте.

Ключевые слова: нарратив, повествование, семиотика, семиотическое пространство, обрывочность, фрагментарность текста.

The article examines the narrative elements of a literary text through the prism of semiotics. It is argued that the structure of a literary text and the use of certain narrative techniques create a unique intra-text semiotic space. Examples of semiotic rows are given, demonstrating the change of narrative techniques in the literary text.

Key words: narrative, semiotics, semiotic space, fragmentariness, semiotic rows.

В связи с повышением интереса к тексту, с осознанием сложности типологии текстовой организации в отечественной филологии возникает дисциплина, изучающая язык художественной литературы, которую стали называть лингвистикой нарратива. Если нарратология исследует нарратив с теоретико-литературоведческих позиций, то лингвистика нарратива предполагает изучение организации повествования в художественном тексте с точки зрения языковедения. Название новой ветви лингвистики текста было предложено в 1995 г. Е.В. 
Падучевой. Она же определила лингвистику нарратива как дисциплину, изучающую «формальные правила извлечения из повествовательного текста всей той семантической информации, которую получает из него человек как носитель языка» [Падучева 1996: 46]. Задачей новой отрасли филологии Е.В. Падучева видит выявление «особенностей употребления и интерпретации языковых элементов в нарративе». Развитие этого направления представляется весьма перспективным, так как «лингвистический анализ литературного нарратива обязательно выходит на постижение его смысла». Исследование художественного текста с учетом нарративных характеристик позволяет делать выводы не только лингвистического, но и функционально-смыслового характера.

Материалом для исследования послужили англоязычный художественный текст одного из наиболее значительных американских писателей XX века Курта Воннегута «Колыбель для кошки» (1963) и его русскоязычный перевод Р. РайтКовалевой (1992). Актуальность данного исследования обусловлена необходимостью выявления зависимостей между структурной и семиотической составляющей текста. Научная новизна работы связана с тем, что в статье рассматривается связь структуры и повествования текста с его семиотическим аспектом. Выявляются отдельные элементы структуры текста, в совокупности составляющее особое семиотическое пространство текста. Целью статьи явилось исследование структурнонарративных особенностей текста. Для исследования семиотической структуры художественного текста используется структурно-семиотическая концепция Ю. М. Лотмана, центральное место в которой отводится понятию «семиосферы». Под семиосферой следует понимать особое культурное пространство, в котором осуществляется знаковая коммуникация и становится возможным семиозис - процесс функционирования знаков и текстов [Егоров 1999: 229]. Семиосфера, согласно Ю. М. Лотману, представляет собой целое «измерение существования», представленное последовательностью знаков (текстами), упорядоченных в соответствии с особой системой кодов. Текст является «своеобразной проекцией культурного пространства [Воробьев, Морозкина, Фаткуллина 2016: 357], что в некоторой степени определяет особенности его структуры и идейного 
содержания. В связи с этим, способ описания структуры семиосферы может быть использован и по отношению к самому тексту как к составляющей единице семиосферы. В работе «Семиосфера» Ю. М. Лотман выделяет разные типы пространств в структуре художественного текста, предполагая «вторжение внешнего пространства (стихии) во внутреннее» [Лотман 2000: 399].

Нарративные особенности текста заключаются в чередовании нарративных техник, используемых автором. Так, текст начинается как журналистское расследование, в ходе которого главный персонаж собирает материалы для своей будущей книги. Затем сюжет делает резкий поворот, меняется место действий (остров Сан-Лоренцо), автор вводит проблему так называемых «банановых» республик, а герой произведения занимает пост президента, что вызывает у реципиента новые ожидания и антиципации. Следующим витком сюжета, перечеркивающим все, с чем был познакомлен читатель ранее, становится внезапное наступление конца света. Текст романа «Колыбель для кошки» не имеет целостной структуры, что характерно для текстов произведений англо-американской литературы, где превалирует особый фрагментарный стиль изложения. Так, присущая фрагментарность нарратива наблюдается и в творчестве М. Твена, Дж. Сэлинджера, Э. Хемингуэя, Дж. Апдайка. Анализируемый в данной статье текст К. Воннегута состоит из 127 коротких глав-отрывков, при этом некоторые из них обладают собственным лейтмотивом, зачастую не коррелирующим с основным ходом повествования. Такая особенность позволяет рассмотреть каждую главу в отдельности и установить, что внезапно обрывающиеся многочисленные сюжетные линии, а порой и персонажи, в совокупности, составляют особое семиотическое пространство текста, связанное с основной, апокалиптической темой произведения. Автор создает систему из множества элементов, одни из которых не связаны друг с другом единым сюжетом, другие не находят продолжения в дальнейшем повествовании. Здесь Воннегут демонстрирует всю сложность мира в целом - состоящего из отдельных жизней и не связанных между собой событий, при этом все рассмотренные элементы семиотического пространства характеризуются незавершенностью и обрывочностью - в основе 
этого лежит идея о том, что так же резко может прерваться и существование мира.

Так, в главе 34 главный герой приходит в мастерскую надгробий Мартина Брида, где обнаруживает необычную статую: "The vin-dit had to do with the stone angel under he mistletoe... The name was my last name, toо” "Мой вин-дит имел отночение к мраморному ангелу под омеловым венком... Там была высечена моя фамилия» [Воннегут 2020: 70]. Факт того, что на статуе высечена фамилия главного персонажа, преподносится автором как немаловажный для сюжета произведения, и, следовательно, вызывает определенную долю интереса у реципиента. Однако, в дальнейшем эта сюжетная линия не находит своего развития, автор намеренно «обрывает» её, нарушая принцип «чеховского ружья». В отдельности стоит отметить работу переводчика, который при переводе данного отрывка успешно использовал приемы конкретизации: stone angel-мраморный ангел; under the mistletoe - под омеловьм венком; и модуляции: the name was my last name, tоо - там была высечена моя фамилия.

Другим примером элемента семиотического пространства данного текста является аналогичным образом оборванная линия той части сюжета, где главному герою достается должность президента вымышленной республики Сан-Лоренцо: "Ме? President?" I gasped... And I agreed to become the next President of San Lorenzo” "Мне? Стать президентом? - ахнул я... Так я согласился стать следуюшим президентом Сан-Лоренцо» [Воннегут 2020: 196]. Реципиент наблюдает новую кардинальную смену нарративов - выстроенный образ главного героя как журналиста-сыщика резко сменяется образом президента республики. При этом антиципации читателя не оправдываются, образ никоим образом не развивается и не получает продолжения - вместо ожидаемого повествования о нахождении главного героя на руководящей должности наступает конец света, после которого уже ничего не имеет значения.

Таким образом, большинство сюжетных линий данного произведения характеризуются незавершенностью, резкой обрывочностью, а общая структура текста фрагментарна. Все незавершенные элементы нарратива якобы «транслируют» сообщение о том, что как внезапно и просто останавливается повествование, таким же образом прекратит свое существование 
все живое после наступления апокалипсиса. Нарративная составляющая в тексте подспудно содержит в себе главную идею произведения, при этом структура текста отнюдь не случайна множество отдельных глав символизируют многообразие и комплексность мира.

Идея незавершенности прослеживается не только в структурном и нарративном компонентах текста, но также и на языковом уровне. Основываясь на лексических средствах, использованных автором, представляется возможным составить лексико-семиотические ряды, которые могут продемонстрировать как смену нарративных техник, так и противоречивую сущность персонажей романа. Как уже было упомянуто, текст романа начинается как журналистское расследование, в ходе которого главный герой пишет книгу о дне, когда на японские города Хиросима и Нагасаки были сброшены ядерные бомбы. Нарратив журналистского расследования подчеркивается рядом глаголов, из которых выстраивается лексико-семиотический ряд: начал собирать (материаль для книги) - была задумана (книга) коснусь (событий) - использую (историю в своей книге) написать (биографию). Таким образом, в начале произведения реципиент настраивается на соответствующее повествование, начинает строить догадки и антиципации. Лексикосемиотический ряд глаголов имеет следующий вид:

Начал собирать - была задумана - коснусь - использую написать;

Began to collect-was to be - gathering-used - to put in.

Однако, вместе с тем, как автор меняет ход повествования, и журналистское расследование сменяется проблемой «банановых» республик, претерпевают изменения и лексические единицы:

Книга что-то не ила - никогда не будет написана - нет представления о чем надо писать - хотел писать;

Loafed on my book - book would never be done - no idea of what it should mean - writing.

Данные ряды отчетливо демонстрируют, как с помощью языковых средств автор сигнализирует реципиенту о смене хода повествования. Первый лексико-семиотический ряд отражает журналистскую фабулу романа, второй лексико-семиотический 
ряд показывает, как она намеренно прерывается автором, для того чтобы ввести в текст следующую линию повествования.

Таким образом, благодаря семиотике нарративов становится возможным более глубокий анализ структуры художественного произведения. Заложенные автором знаки, скрытые в отдельных языковых единицах, в совокупности позволяют реципиенту понять идею произведения на разных уровнях смыслообразования. При этом важен корректный перевод соответствующих языковых единиц, так как любая неточность может отразиться на общем восприятии персонажа читателем.

\section{ЛИТЕРАТУРА}

1. Kurt Vonnegut. Cat's Cradle. New York: Dell Publishing, 1963.117p.

2. Воннегут, К. Колыбель для кошки // пер. с англ. Р. Райт-Ковалевой. Москва. Издательство АСТ, 2020. $282 \mathrm{c}$.

3. Воробьев В. В., Морозкина Е. А., Фаткуллина Ф. Г. Триада язык - культура - личность как основа современной лингвокультурологии // Вестник БашГУ. 2016. Т. 21. №2. С. 355-358.

4. Гриненко Г. В. Семиосфера и семиотика культуры // Культура и образование. 2013. №1(10). С. 32-39.

5. Егоров Б. Ф. Жизнь и творчество Ю. М. Лотмана. М.: НЛО, 1999. 384 с.

6. Лотман Ю. М. Семиосфера. СПб: Искусство-СПБ, 2000. 704 c.

7. Падучева Е. В. Семантические исследования. Семантика времени и вида в русском языке. Семантика нарратива. М.: Языки славянской культуры, 1996. Изд. 2 -е, 2010, 480 с.

(C) Терентьев О.С., 2021 г. 